\title{
SATU TUHAN TIGA AGAMA (YAHUDI, NASRANI, ISLAM DI YERUSALEM)
}

\author{
Amaliyah \\ Universitas Pamulang Tangerang \\ E-mail: amaliyahnasrudin@gmail.com
}

\begin{abstract}
This study describes the difference in perspective about the One God in three religions, namely, Yaudi, Christianity, Is lam. Based on the history of the three religions in addition to having a difference they have a similar though all three are related to each other. The equation is the same concept that is based on monotheism Unita rian deity This doctrine expresses the belief in one God. However, based on the understanding is different because more Jews speak rules of survival, al is illustrated in ten rules God (ten Comandemen) while Christian was first talked about the role of God, it is envisaged that God can be as Creator (God) acts as a savior, too as human beings, have the same activities as men in general. while Islam speaks about-ness of it reflected in the Muslim holy book ie the Qur'an in Qs. Al-Ikhlas monotheism which is the heart of Islam.
\end{abstract}

Keywords:

Monotheism, doctrine, similar

\begin{abstract}
Abstrak
Studi ini menjelaskan tentang perbedaan prespektif mengenai ke-Esaan Tuhan di tiga agama yaitu, Yaudi, Nasrani, Islam. Berdasarkan sejarah ketiga agama tersebut selain memiliki perbedaan mereka juga memiliki persamaan walaupun ketiganya saling berkaitan satu sama lain. Persamaannya mengenai konsep yang sama yaitu didasarkan pada Unitarian monoteisme dalam ketuhanan Doktrin ini mengekspresikan kepercayaan pada satu Tuhan. Namun berdasarkan pemahaman tentu berbeda karena Yahudi lebih berbicara aturan hidup,al ini tergambar dalam sepuluh aturan Tuhan (ten Comandemen) sedangkan nasrani pertama kali berbicara tentang peran Tuhan, hal ini tergambar bahwa Tuhan bisa sebagai Pencipta (Tuhan Allah) berperan sebagai sang penyelamat, juga sebagai manusia biasa, memiliki kegiatan yang sama seperti manusia pada umumnya. sedangkan Islam berbicara tentang Ketauhidan hal ini tergambar dalam kitab suci umat Islam yaitu Al-Qur'an dalam Qs. Al-Ikhlas yang merupakan jantung bagi ketauhidan umat Islam.
\end{abstract}

Kata Kunci:

Monotaisme, doktrin, Persamaan

\section{A. PENDAHULUAN}

Konsep agama yang bersifat politeisme dan menyembah berdasarkan sifat-sifat kekuatan benda atau imajinasi dari manusia adalah awal dari pencarian kekuatan yang lebih dari manusia atau alam semesta. Hal tersebutlah yang membuat manusia menyembah matahari, lautan, gunung, pohon besar, dan hingga patung-patung yang dianggap memiliki kekuatan dan memberi kehidupan. Perjalanan sejarah para nabi pada pernyataannya memberi garis merah tentang satu hal yaitu ketauhidan kepada Allah. Berpijak pada hal tersebut ketika adanya esensi substansi tuhan yang berbeda berarti ada penyimpangan yang dilakukan oleh manusia dalam keterbatasan pemikirannya. Juga dimungkinkan karena proses kabar yang memerlukan waktu, disebabkan jarak yang harus ditempuh dengan perjalanan tradisional (jalan kaki) pada masa itu.

Periode setelah nabi Adam pun semua nabi-nabi mengajarkan ajaran keesaan Allah sebagai pencipta alam semesta ini. Pembuktian kisah pencarian tuhan seperti yang dijelaskan oleh Allah dalam firmannya surat al anam ayat 76-79 yaitu ketika nabi Ibrahim mencari sebuah hakikat Tuhan. Ajaran tentang keesaan Allah disampaikan oleh para nabi dan rasul. Seperti firman Allah dalam Q.S: AlAnbiya':25 ; 'Dan tidaklah kami mengutus sebelum engkau seorang Rasulpun melainkan kami wahyukan kepadanya: bahwasanya tiada Tuhan yang sebenarnya disembah melainkan Aku, maka sembahlah Aku.”. Kerasulan nabi ada yang dikabarkan dalam kitab namun ada yang tidak dikabarkan. Hanya saja menjadi sesuatu yang istimewa dan ada kekhususan 
ketika itu dikabarkan dalam kitab suci seperti kedatangan rasul Muhammad SAW sudah diramalkan sebelumnya. Dalam Al Quran Qs. 61 Ash Shaff 6 "dan (ingatlah) ketika Isa Ibnu Maryam berkata: "Hai Bani Israil, Sesungguhnya aku adalah utusan Allah kepadamu, membenarkan kitab sebelumku, Yaitu Taurat, dan memberi khabar gembira dengan (datangnya) seorang Rasul yang akan datang sesudahku, yang namanya Ahmad (Muhammad). "Maka tatkala Rasul itu datang kepada mereka dengan membawa bukti-bukti yang nyata, mereka berkata: "Ini adalah sihir yang nyata." Dalam kitab Ulangan (pasal 18, ayat 17-22), Nabi Musa bersabda, "Maka pada masa itu berfirmanlah Allah kepadaku, 'Benarlah kata mereka, Bani Israil itu, bahwa Aku, Allah, akan menjadikan bagi mereka seorang nabi dari antara segala saudaranya, yakni dari Bani Ismail, yang seperti engkau, hai Musa. Dan Aku akan memberi segala firman-Ku dalam mulutnya, dan dia pun akan mengatakan kepadanya segala yang Aku suruh'." Di Injil Yahya (Perjanjian Baru) pasal 14, ayat 16-17, yang menyebut-nyebut perihal "Roh Kebenaran", yang dalam bahasa Yunani disebut Paraclet atau Para-Cletos atau Paracletos, yang bermakna Yang Terpuji. Dan dalam bahasa Arab, Muhammad memang berarti Yang Terpuji. Nabi Muhammad mengajarkan untuk percaya kitab-kitab zabur, taurat, injil.

Konsep pada agama yahudi, nasrani, islam dalam ketuhanan didasarkan pada Unitarian monoteisme. Doktrin ini mengekspresikan kepercayaan pada satu Tuhan. Al Kitab Ibrani mengatakan : "Dengarkan Israel, Tuhan adalah Allah kita, Tuhan adalah satu". Al Kitab Injil (ulangan 32;39 mengatakan "Lihatlah Aku Allah yang Esa, Tak ada Allah kecuali Aku”. Al Quran (Al Ikhlas 1) “ Katakanlah: "Dia-lah Allah, yang Maha Esa". Dari ketiga kitab tersebut sudah jelas adanya substansi bahwa Allah-lah Tuhan dari Yahudi, Nasrani dan Islam. Hanya dalam perkembangannya semua berkembang dengan prinsip kebenarannya sendiri-sendiri dalam bidang syariahnya, sedang dalam akidah prinsipnya mempercayai keesaan Allah.

\section{B. HASIL DAN PEMBAHASAN \\ 1. Esensi dari kitab-kitab yahudi, nasrani, Islam}

Kata Taurat bersumber dari bahasa Ibrani: "Thora" yang berarti syariat atau hukum. Kitab Taurat itu sendiri memang diturunkan dalam bahasa Ibrani. Isi pokok kitab ini yakni Sepuluh firman atau Perintah (Ten Commandements) Allah SWT yang diterima oleh Nabi Musa as. saat berada di puncak gunung Thursina. Sepuluh Firman atau Perintah yang berisi asas-asas akidah (keyakinan) dan asas-asas syariat (kebaktian) itu tercantum dalam kitab Keluaran pasal 20: 1-17 dan Kitab Ulangan pasal 5: 1-21. Sepuluh Perintah Allah SWT itu sebagai berikut: keharusan mengakui ke-Esa-an Allah dan mencintai-Nya. Larangan menyembah berhala atau patung, sebab Allah SWT tidak dapat diserupakan dengan makhluk-makhluk-Nya baik yang ada di langit, di darat, maupun di air. Perintah menyebut nama Allah SWT dengan hormat. Perintah memuliakan hari Sabat (sabtu). Perintah menghormati ayah-ibu. Larangan membunuh sesama manusia. Larangan berbuat cabul (mendekati zina). Larangan mencuri. Larangan berdusta (menjadi saksi palsu). Larangan berkeinginan mempunyai atau menguasai barang orang lain dengan cara yang tidak tepat. Selain Sepuluh Firman atau Perintah Allah SWT itu, Nabi Musa as juga menerima wahyu lain tentang cara melakukan sholat, berqurban, upacara, dan lain sebagainya. Dalam menyiarkan ajaran tersebut, Nabi Musa as., dibantu oleh saudaranya, Nabi Harun as.

Kata Injil semula bersumber dari bahasa Yunani euangelion yang bermakna kabar gembira. Kemudian diterjemahkan ke dalam bahasa Arab menjadi Injil. Arti dari kabar gembira yang dimaksud adalah karena Nabi Isa as menggembirakan umat-umatnya dengan berita akan kedatangan Nabi Muhammad saw sebagai utusan Allah SWT yang terakhir untuk seluruh alam. Selain berisi keesaan Allah, puji-pujian juga mengajak zuhud yakni pola hidup yang tidak mengutamakan hal-hal yang bersifat duniawi. Isi Injil Barnabas $^{1}$

\footnotetext{
1 Pada tahun 1709, Cremer Toland (penasihat Raja Prusia) menemukan teks tertua Injil Barnabas dalam
} 
banyak persamaannya dengan yang diberitakan Al-Quran. Sebab dalam kitab tersebut diterangkan bahwa: Yesus tidak disalib, yang disalib sebenarnya Yudas Iskariot yang telah diserupakan oleh Tuhan (rupa dan suaranya) dengan rupa dan suara Yesus. Sedangkan Yesus sendiri loncat bersama malaikat dan terus diangkat ke hadirat Allah SWT (Pasal 215, 216, dan 217). Yesus bukanlah anak Allah, bukan pula Tuhan, tetapi seorang Rasul (utusan) Allah. Bahwa putra Nabi Ibrahim as yang akan disembelih karena perintah Allah SWT adalah Ismail. Mesias (yang dimaksudkan di sini adalah "pembebas dunia" atau "juru selamat") atau Almasih yang dinantinantikan tersebut bukan Yesus akan tetapi Nabi Muhammad, yang merupakan Nabi dan Rasul Allah yang terakhir.

Injil Dicache yaitu Injil perspektif baru yang terungkap di Yerusalem, memuat 20 butir kabar gembira tentang Nabi Muhammad SAW. Pertama, seluruh kitab samawi (baik Taurat maupun Injil) menyebutkan bahwa AlMasih Pemimpin adalah sosok yang mampu meruntuhkan kekaisaran Romawi. Melainkan keruntuhannya pada masa Nabi Muhammad. Kedua, Injil Didache tidak menyebutkan bahwa nabi Isa adalah nabi yang akan diutus di akhir zaman. la justru mengatakan bahwa penganut Kristen yang tidak mengimani Nabi Muhammad akan dikutuk. Ketiga, Sebutan orang Kristen (AI-Masihi) baru diberikan kepada murid-murid Yesus (An-Nashara) setelah AI-Kitab diubah pada Konsili Niqiyyah tahun 325 M. Keempat, orang-orang Yahudi memberikan sebutan 'Mesias' atau 'Al-Masih Pemimpin' kepada nabi yang sangat ditunggu-tunggu yang akan datang seperti Musa. Mereka menyebutkan bahwa julukan "Anak Tuhan" dan julukan 'Tuhan' di dalam

bahasa Italia yang semula tersimpan rapi pada perpustakaan seorang terkemuka di Amsterdam. Dari naskah berbahasa Itali itulah dibuat terjemahannya ke bahasa lain seperti bahasa Inggris, Spanyol dan Arab oleh Dr. Kholil Sa'adah pada tahun 1908 dan ditulis dalam majalah Al Manar terbitan Mesir. Dari Injil Barnabas berbahasa Arab itulah, Husein Abubakar dan Abubakar Basymeleh menerjemahkannya ke dalam bahasa Indonesia.
Mazmur adalah julukan-julukan nabi itu. Sedangkan Isa menolak julukan tersebut.

Dimensi isi yang termaktub dalam Taurat dan Injil juga dijelaskan kembali dalam AlQuran. Esensi dalam ketiga kitab tersebut yang mengharuskan untuk mempercayai keesaan Allah dan mempercayai Rasul terakhir yaitu nabi Muhammad SAW. Lalu kenapa masih ada perbedaan diantara Yahudi, Nasrani dan Islam yang berasal dari satu tuhan. Pengingkaran beberapa waktu lamanya sesudah Nabi Musa as wafat, isi kitab Taurat telah diubah oleh pemuka Yahudi. Beberapa firman Allah SWT dalam kitab tersebut mereka gelapkan, sebagaimana telah difirmankan oleh Allah SWT dalam Al Qur'an. "Dan mereka tidak memuliakan Allah dengan kemuliaan yang semestinya saat mereka berkata: "Allah tidak menurunkan sesuatu pun kepada manusia." Jawablah (ya Muhammad): "Siapakah yang menurunkan kitab (Taurat) yang dibawa oleh Musa sebagai cahaya dan petunjuk bagi manusia, kamu jadikan kitab itu lembaran-lembaran kertas yang berceraiberai, kamu perlihatkan (sebagiannya) dan kamu sembunyikan sebagian besarnya, padahal telah diajarkan apa yang kamu dan bapak-bapak kamu belum ketahui." Katakanlah: "Allah (telah menurunkannya)". Kemudian biarkanlah mereka bermain-main dalam kesesatannya." (QS. Al An'am: 91). Demikian juga pengingkaran yang dilakukan oleh pengikut nabi Isa yang menganggap sebagai Tuhan atau anak Tuhan yang disalib. Dijawab dalam firman Allah dalam QS. Ali 'Imraan: 55 dan QS. An-Nisaa': 155-159.

Munculnya aliran di masing-masing agama tersebut, menghilangkan esensi dari ketauhidan kepada Allah. Di Islam muncul beragam aliran termasuk aliran-aliran sesat yang sekarang menjadi perbincangan adalah aliran Syiah dan Wahabi. Di agama Nasrani juga terdapat perbedaan paham yang memunculkan paham Khatolik, Protestan, Ortodox, ditambah kitab suci Injil yang beraneka versi penulis. Di agama Yahudi juga terbagi yang taat (ketaatan pada keesaan Allah) dan ingkar (berupa penyembahan setan (Luciferian), nama ilmunya sihir kabbalah). 
Aksioma mendasar yang senantiasa diketengahkan oleh Zionisme (bangsa Yahudi) terhadap bangsa Nasrani sebagai sebuah gerakan politik "jika terdapat buku Injil serta bangsa Injil maka haruslah terdapat pula negeri Injil para hakim serta para keluarga di Yerusalem, Hebron, Yericho dan negri-negri yang berada di sekitarnya. ${ }^{2}$ Agama Nasrani ini meluas dibawa oleh Paulus sampai ke Yunani dan Eropa. Ajaran Paulus yang dianggap baru ialah anggapan bahwa Yesus adalah Kristus atau Tuhan. Padahal ia bukan murid Yesus dan belum pernah berjumpa dengan Yesus. ${ }^{3}$ Sehingga memunculkan konsep baru adalah sebagaimana termuat dalam kredo iman rasuli yaitu Tritunggal yang meliputi dari Allah Bapa, Allah Putera dan Roh Kudus. Ketiganya adalah pribadi Allah dan pribadi tersebut adalah Allah. ${ }^{4}$ Kitab yang masih terdapat kesamaan dengan $\mathrm{Al}$-Quran adalah dalam $\mathrm{Al}$ Kitab perjanjian lama (Bibel), sedangkan kitab yang beredar sekarang adalah kitab perjanjian baru yaitu Markus (60 M), Matius (70 M), Lukas (75 M), dan Yahya (100 M). Ditambah adanya tradisi yang dilakukan oleh pihak gereja tentang Traditio Dekratative yang artinya gereja adalah satu-satunya badan yang dapat menjelaskan isi kitab tanpa berbuat salah. Kedua, Traditio Konstituve, yaitu gereja memiliki tradisi yang melengkapi isi kitab suci. Sehingga tidak dimungkinkan para pengikut bangsa Nasrani untuk melakukan kritik analisis pada ajaran tersebut. Termasuk dalam konsep syariah bangsa Nasrani yaitu menghalalkan apa yang telah diharamkan Allah. Contoh: membolehkan memakan daging babi. Dalam konsep ibadah, ditandai dengan melakukan tata cara peribadatan yang tidak diperintahkan Allah. Contoh: berdo'a, tunduk, atau sujud di hadapan patung. Padahal dalam 10 Perintah Tuhan di Exodus 20:4-5 Allah melarang manusia membuat patung apa

\footnotetext{
${ }^{2}$ R. Garaudy, Zionis, Sebuah Gerakan Keagamaan dan Politik, Jakarta, buku andalan, 1991, hal. 151

${ }^{3}$ Djam'annuri, Agama Kita: Perspektif Sejarah Agamaagama: Sebuah Pengantar, (Yogyakarta: Kurnia Kalam Semesta, 2002), 81.

4 A.D. El Marzdedeq, Parasit Aqidah, (Bandung: Syaamil Cipta Media, 2005), 289
}

pun: 20:4 Jangan membuat bagimu patung yang menyerupai apapun yang ada di langit di atas, atau yang ada di bumi di bawah, atau yang ada di dalam air di bawah bumi. 5 Jangan sujud menyembah kepadanya atau beribadah kepadanya, sebab Aku, TUHAN, Allahmu, adalah Allah yang cemburu, yang membalaskan kesalahan bapa kepada anakanaknya, kepada keturunan yang ketiga dan keempat dari orang-orang yang membenci Aku (Exodus 20:4-5).

\section{Perang dingin Yahudi, Nasrani, Islam di Yerussalem}

Yerussalem atau 'Daarussalaam", kota yang disucikan Islam, Kristen dan Yahudi. Perebutan kekuasaan di Yerussalem karena tambang yang dihasilkan laut mati bernilai milyaran dolar, bukan pula karena cadangan minyak melebihi cadangan yang ada di Amerika Utara dan Selatan, tetapi memang berpegang pada ajaran Taurat. Dan karena Palestina adalah titik pusat paling vital bagi kekuatan dunia, dan merupakan pusat strategis kemiliteran yang bisa dijadikan tonggak untuk menguasai dunia. ${ }^{5}$ Kawasan itu adalah kawasan strategis yang menghubungkan antara Asia, Afrika dengan Eropa. Dan dengan doktrin aqidah yang demikian kuat, diwariskan dari satu generasi ke generasi berikutnya. Yerusalem menjadi kota suci tiga agama, dimana kisah sejarah perjuangan para nabi berada.

Nabi Musa dilahirkan di Mesir (1593 SM). Ayah ibunya berasal dari suku Lewi, salah satu suku yang dinasabkan pada salah seorang putra Ya'qub dengan istrinya Liah. ${ }^{6}$ Ajaran Taurat "setiap orang Yahudi harus menyatakan perang suci menentang kejahatan". Keyakinan yang dipegang Yahudi, yang membawa mereka kepada kemenangan dan penuh dinamis, difokuskan kepada Taurat dan ajaran para nabi taurat hukum, tidak hanya berkaitan dengan cara-cara bertingkah laku yang baik, benar dan moral melainkan pula merupakan pengetahuan tentang Tuhan dan kehendak

\footnotetext{
5 William G. Carr, Yahudi Menggenggam Dunia, Jakarta, Pustaka Al Kautsar, hal. 32

${ }^{6}$ Bahrudin Daya, Agama Yahudi. 1982. Yogyakarta: PT Bagus Arafah. Hal. 56
} 
Tuhan. Karena penindasan pada bani Israel di mesir maka nabi Musa mengajak untuk berpindah ke negara yang dijanjikan tuhan (Yehovah), akan tetapi nabi Musa meninggal dunia pada usia 120 tahun di Bukit Nabu', tempat diperintahkan Allah untuk melihat tempat suci yang dijanjikan, yaitu Palestina, tetapi beliau tidak sempat memasuki Palestina. Sepeninggal Musa as, bangsa Yahudi kembali ingkar dalam keimanan kepada Allah.

Tuntutan bangsa Yahudi tetap menghendaki Yerussalem, itupun setelah ada eksodus besarbesaran dari Eropa setelah ditemukan kelicikan bangsa Yahudi. Islam di Yerussalem menolak dengan alasan, pertama, bahwa wilayah ini diberikan pada bangsa Yahudi saat mereka menjunjung tinggi tauhid di bawah kepemimpinan para rasul Musa. Kedua, jika berdasarkan garis keturunan, maka bukan hanya Bani Israel yang berhak mengklaim bahwa mereka merupakan satu-satunya yang berhak atas kepemimpinan. Pasalnya, Ismail as beserta keturunannya pun berhak atas janji yang diberikan pada Ibrahim. Ketiga, Secara historis, pemerintahan Bani Israel di Palestina hanya 4 abad di sebagian wilayah Palestina. Sedangkan pemerintahan Islam berlangsung selama 12 abad (636-1917 M). Keempat, sebagian besar bangsa Yahudi telah meninggalkan wilayah Palestina, dan mereka terputus kontak dengan negeri tersebut selama 18 abad (sejak $135 \mathrm{M}$ sampai abad 20).

Perang dingin juga terjadi antara bangsa Yahudi dan Nasrani, bahwa dalam akidah kaum nasrani, bahwa kaum yahudi telah menyalib Isa Al masih. Sedang kaum yahudi tidak mengakui kerasulan Isa apalagi mempercayai sebagai tuhan. Dari sinilah bermula permusuhan yang turun temurun sepanjang zaman antara kaum yahudi dan nasrani. ${ }^{7}$ penindasan kaum yahudi diseluruh dunia atas nama Isa Almasih. Dan pembersihan dari bangsa yahudi tersebut pada masa pemerintahan Adolf Hitler (1933-1945), Pemerintah Inggris Yohana Friedrik (1539) mengusir dan tak sedikitpun boleh melintas

\footnotetext{
7 Asy-Syekh As'ad Bayudh Attamimi, Impian Yahudi dan Kehancurannya Menurut Al Quran, Jakarta, Gema Insan Press, 1994, hal. 51
}

Didasarkan pada keputusan ajaran Martin Luther. Pemerintahan perancis (1845), Austria dan hongaria (1871), eropa timur(1905), Eropa dan amerika (1914) semua menutup dari bangsa yahudi. Adapun perselisihan bangsa nasrani dengan islam, selain akidah juga dipicu oleh sejak penaklukan bangsa Arab terhadap Palestina dari kekuasaan Kekaisaran Bizantium pada abad ke-7. Hal ini sebenarnya tak terlalu memengaruhi penziarahan ke tempat-tempat suci umat Kristiani atau keamanan dari biara-biara dan masyarakat Kristen di Tanah Suci Kristen tersebut. Sementara itu, bangsa-bangsa di Eropa Barat tak terlalu perduli atas dikuasainya Yerusalem yang berada jauh di Timur hingga ketika mereka sendiri mulai menghadapi invasi dari orang-orang Islam dan bangsa-bangsa nonKristen lainnya misalnya bangsa Viking dan Magyar. Namun, kekuatan bersenjata kaum Muslim Turki Saljuk yang mampu memberikan tekanan yang kuat kepada kekuasaan Kekaisaran Byzantium yang beragama Kristen Ortodoks Timur. ${ }^{8}$ Namun ketika itu umat Kristiani merasa tidak lagi bebas untuk menunaikan ibadah di sana. Mereka yang pulang dari ziarah sering mendapat perlakuan buruk dari orang-orang Seljuk. Selain itu pula khalifah Abdul Hakim menaikkan pajak ziarah untuk orang-orang Kristen Eropa. Hal tersebut memicu kemarahan Paus Urbanus II yang menyebutkan bahwa hal tersebut merupakan perampokan dan sebuah kewajiban untuk merampas kembali Baitul Maqdis . Selain itu, Paus pun menjanjikan kejayaan, kesejahteraan, emas, dan tanah di Palestina, serta surga bagi para ksatria yang mau berperang.

Yerussalem adalah tempat yang sangat sakral bagi tiga agama. Bagi bangsa yahudi, tempat bagi Kotel, atau Tembok Barat atau dikenal sebagai Tembok ratapan. Kaum Yahudi meyakini bahwa lokasi ini merupakan lokasi batu fondasi penciptaan bumi, dan tempat dimana Ibrahim bersiap untuk mengorbankan anaknya Ismail. Bagi bangsa nasrani terdapat situs Gereja Makam Kudus, yang menjadi situs tujuan ziarah bagi umat Kristen

\footnotetext{
${ }^{8}$ Sanusi, Ahmad. Relasi Damai Islam Kristen. Pustaka Alvabet, 2001.
} 
di seluruh dunia, yang terletak di Golgotha, atau bukit Calvary. Bagi umat Islam terdapat tempat suci Dome of Rock dan Masjid the alAqsa serta dataran tinggi yang dikenal sebagai Haram al-Sharif oleh kaum Muslim. Juga perjalanan malam yang disebut Isra Mi'raj, diyakini pula di Masjid al-aqsa Nabi Muhammad sholat bersama dengan roh seluruh nabi.

Yahudi, nasrani, islam dengan keyakinan kebenarannya ingin menguasai yerusalem (tanah suci) berdasar pada kitab suci dan sejarah kenabian mereka. Sampai hari ini peperangan antara yahudi dan nasrani, yahudi dan islam, nasrani dan islam terus terjadi di yerusalem dengan berbagai macam penyebabnya.

\section{SIMPULAN}

Dari uraian sejarah dan uraian kitab yang singkat, dapat disimpulkan bahwa Tuhan satu tidak memberi ajaran akidah, syariah dan akhlak yang berbeda diantara Yahudi, Nasrani, Islam akan tetapi penegasan ketauhidan Allah dan penyempurnaan ajaran-Nya. Pemikiran bangsa yahudi sendirilah yang dalam sejarah tidak mengakui kerasulan dari nabi Isa dan nabi Muhammad. Juga pemikiran bangsa nasrani yang juga tidak mengakui kerasulan ajaran nabi Muhammad. Ketidaktaatan bangsa Yahudi dan Nasrani dilakukan dengan membuat penyimpangan kitab Taurat dan kitab Injil, yang tidak dapat dibuktikan keasliannya. Meskipun demikian tetap ditemukannya ajaran yang sama dengan Al-Quran sebagai kitab yang terakhir.

Perang terus akan berkecambuk hingga akhir zaman. Karena seluruh kitab baik Taurat, Injil dan Al-Quran telah mengkabarkan peperangan ini. Namun demikian sebagai manusia yang beragama, kita wajib melakukan ikhtiar agar bangsa Yahudi, bangsa Nasrani, Islam hidup berdampingan dan tidak menumpahkan darah di tanah suci Yerussalem.

\section{DAFTAR PUSTAKA}

Abdurrahman Arrifai, Fuad bin Sayyid. Yahudi dalam Informasi dan Organisasi, Jakarta:Gema Insane Pers.
A.Joy Global Media, Perancis Tuan Rumah Konferensi Internasional untuk Perdamaian Timteng, 20 Januari 2017.

As'ad Bayudh attamimi, Asy-Saekh. Impian Yahudi dan Kehancurannya Menurut AlQuran, Jakarta:Gema Insane Press, 1994.

Daya, Bahrudin. Agama Yahud, Yogyakarta: PT Bagus Arafah,1982.

Daya, Bahrudin. Agama Yahudi, Yogyakarta: PT Bagus Arafah. 1982.

Djam'annuri. Agama Kita: Perspektif Sejarah Agama-Agama (Sebuah Pengantar), Yogyakarta: Kurnia Kalam Semesta, 2002.

El Marzdedeq, A.D. Parasit Aqidah, Bandung: Syaamil Cipta Media, 2005.

Fathuddin, Ja'far. Dunia Islam Versus Tata Dunia Baru. Jakarta:LPPD Khairu Ummah, 1994.

G. Carr, William . Yahudi Menggenggam Dunia, Jakarta:Pustaka Al Kautsar.

Garaudy, R. Zionis (Sebuah Gerakan Keagamaan dan Politik), Jakarta: Buku Andalan, 1991.

Hermawati. Sejarah Agama dan Bangsa Yahudi, Jakarta: Rajawali Pers, 2004.

Khalifah Hasan, Muhammad. Sejarah Agama Yahudi, Jakarta:Pustaka Al Kausar, 2009.

Muslim, Era. Senin, 25 Rabiul Akhir 1438 H / 23 Januari 2017.

Rahman Ansari, Fazlur. Islam dan Kristen (Dalam Dunia Modern), Jakarta:Amzah

Ridha, Abu. Palestina, Nasibmu Kini. Jakarta: Yayasan SIDIK, 1994.

Ridha, Abu. Rencana Zionis Melumpuhkan Shahwah Islamiyah. Jakarta:Yayasan SIDIK, 1995.

Sanusi, Ahmad. Relasi Damai Islam Kristen, Pustaka Alvabet, 2001 